\title{
KEMAMPUAN KOMUNIKASI MATEMATIS SISWA KELAS VII SMP NEGERI 1 MOJOLABAN TAHUN PELAJARAN 2014/2015
}

\author{
Nor Khoiriyah $^{1}$, Imam Sujadi ${ }^{2}$, Sri Subanti ${ }^{3}$ \\ ${ }^{1,2,3}$ Prodi Magister Pendidikan Matematika, FKIP Universitas Sebelas Maret Surakarta
}

\begin{abstract}
The purpose of this research was to describe the ability of student's mathematical communication who had low, medium, and high early mathematics ability in class VII SMP Negeri 1 Mojolaban on aspect grammatical, sociolinguistic, strategic, and discourse competence in solving mathematics problem. This research was a qualitative research. The subjects in this research were seven students of class VIIE SMP Negeri 1 Mojolaban, which consisted of three students who had low early mathematical ability, two students who had medium early mathematics ability, and two students who had high early mathematical ability.The subjects in this research were taken by using the purposive sampling technique. The main instrument used in this research to collect the data was the researcher and the other instrument were a task that contains of test question and interview guide instrument. Data analysis technique were conducted by data reduction, data presentation and conclusion. The validity of the data was conducted by using time triangulation that compared the data of the first task based interviews with the data of the second task based interviews. The equal valid data of mathematical communication ability on aspect grammatical, sociolinguistic, strategic, and discourse competence was made the main finding, whereas the different of valid data was made other finding of the research. The result of this research are the students who had low, medium, and high early mathematics abilities were have imperfect mathematical communication on grammatical, sociolinguistic, strategic, and discourse competence. The imperfection that appear on each competence caused by some indicators that not fulfilled completely.
\end{abstract}

Keywords: Mathematical communication, grammatical competence, discourse competence

\section{PENDAHULUAN}

National Council of Teachers of Mathematics (NCTM) menjadikan kemampuan berkomunikasi sebagai salah satu standar proses yang tercantum dalam prinsip-prinsip pembelajaran matematika. National Council of Teachers of Mathematics (NCTM) (2000:20) menjelaskan bahwa para siswa harus belajar matematika dengan cara aktif membangun pengetahuan baru dari pengalaman dan pengetahuan sebelumnya. Belajar matematika tidak hanya memerlukan ketrampilan menghitung, tetapi juga memerlukan kecakapan untuk berpikir dan beralasan secara matematis. Kegiatan belajar siswa dapat ditingkatkan dengan cara menilai ide-ide temannya, didorong untuk membuat dugaan tentang matematika, lalu mengujinya dan mengembangkan ketrampilan memberi alasan yang logis. Ontario Ministry of Education (2010) menyatakan bahwa melalui komunikasi matematis, siswa dapat merenungkan, menjelaskan, dan memperluas ide-ide, serta memahami hubungan matematika dan argumen matematika. Oleh karena itu, setiap siswa perlu memiliki kemampuan komunikasi matematis yang baik.

Kemampuan komunikasi matematis adalah kecakapan siswa dalam mengungkapkan ide-ide matematika dengan menggunakan simbol, notasi, bahasa, atau 
kalimat matematika. Pentingnya kemampuan komunikasi matematis bagi siswa kurang diimbangi dengan kenyataan di lapangan. Menurut Ali Mahmudi (2009:1), pada umumnya siswa dapat melakukan berbagai perhitungan matematik, tetapi kurang menunjukkan hasil yang menggembirakan terkait dengan kemampuan matematika aplikatif seperti mengoleksi, menyajikan, menganalisis, menginterpretasikan data, serta mengomunikasikannya. Lee (Kosko dan Wilkins, 2011:81) menjelaskan bahwa terkadang siswa merasa kesulitan mencapai pemahaman dengan jenis bahasa matematika yang biasa terdapat dalam buku-buku teks atau yang digunakan guru, sehingga mereka menggunakan bahasa informal untuk memahami konsep. Kongthip et al (2012) bahkan menemukan bahwa siswa kelas 5 SD menggunakan beberapa jenis gerakan tubuh (gestures) untuk dapat menjelaskan jawaban matematika. Hal ini menunjukkan bahwa masih banyak siswa yang mengalami kesulitan dalam berkomunikasi secara matematis.

Olivares (1996:219) menjelaskan bahwa siswa mula-mula akan mengamati bahasa tubuh, lingkungan, dan hubungan kata-kata dari suatu pesan. Pada situasi tersebut, mereka dapat menggunakan ide atau gagasan berdasarkan intuisi untuk menduga maksudnya. Meskipun demikian, apa yang telah dilakukan siswa tersebut bukan sepenuhnya bentuk dari komunikasi matematis. Siswa perlu bekerja dengan abstraksi dan simbol-simbol agar dapat berkomunikasi secara matematis. Olivares (1996:220-224) membagi kemampuan komunikasi matematis ke dalam empat macam aspek kemampuan, yaitu kemampuan gramatikal (gramatical competence), sosiolinguistik (sociolinguistic competence), strategis (strategic competence), dan kemampuan memahami wacana (discourse competence). Kemampuan komunikasi matematis pada aspek gramatikal merupakan kecakapan siswa dalam merumuskan definisi dari suatu istilah matematika serta kecakapan dalam menggunkan simbol atau notasi matematika secara tepat. Kemampuan sosiolinguistik merupakan kecakapan siswa dalam menyelesaikan permasalahan kontekstual secara matematis. Dengan menguasai kemampuan sosiolinguistik, seorang siswa dapat menyatakan bahasa sehari-hari ke dalam bahasa matematis, begitu juga sebaliknya. Selanjutnya, kemampuan strategis merupakan kecakapan siswa dalam mendeskripsikan strateginya. Siswa dengan kemampuan strategis yang baik dapat mengetahui apakah data yang diperlukan sudah cukup atau mereka perlu menggali lebih banyak lagi informasi agar dapat menyelesaikan soal. Kemampuan memahami wacana merupakan kecakapan siswa dalam menangkap informasi deskripsi dari soal secara menyeluruh, sehingga siswa dapat mengungkapkan gagasan secara verbal dengan argumen atau penjelasan yang logis dan sesuai dengan konsep. Masingmasing aspek kemampuan komunikasi matematis tersebut saling berhubungan dan mempengaruhi jawaban siswa ketika menyelesaikan soal. 
Penelitian tentang kemampuan komunikasi matematis juga dilakukan oleh Zavy (2012). Penelitian Zavy (2010) bertujuan untuk menggambarkan kemampuan komunikasi matematis kelas unggulan dan kelas reguler siswa SMA. Penelitian ini tidak mengacu pada aspek kemampuan gramatikal, sosiolinguistik, strategis, dan kemampuan memahami wacana, tetapi lebih pada bentuk pelevelan terhadap kemampuan komunikasi matematis siswa. Hasil penelitian ini menunjukkan bahwa siswa kelas unggulan dapat mencapai level yang lebih tinggi dibandingkan siswa kelas reguler, dimana siswa kelas unggulan dapat mencapai level 4 dan 3, sedangkan siswa kelas reguler berkisar pada level 0, 1, dan 2. Berdasarkan penelitian Zavy (2012) ini, peneliti ingin mengetahui bagaimana kemampuan komunikasi siswa kelas reguler yang berkemampuan awal matematika rendah, sedang, dan tinggi tetapi dikhususkan pada pengamatan karakteristik kemampuan gramatikal, sosiolinguistik, strategis, dan memahami wacana. Pengambilan kategori siswa berdasar pada kemampuan awal matematika rendah, sedang, dan tinggi ini diharapkan dapat membantu guru memperoleh gambaran menyeluruh tentang komunikasi matematis siswa di dalam kelas.

Berdasarkan data prasurvei sebelum penelitian, peneliti dapat mengindikasikan bahwa kemungkinan siswa SMP Negeri 1 Mojolaban cukup baik pada aspek gramatikal, tetapi mengalami kelemahan pada aspek kemampuan komunikasi matematis lainnya, seperti kemampuan sosiolinguistik, strategis, maupun kemampuan memahami wacana. Oleh karena itu, peneliti perlu melakukan penelitian lebih jauh untuk mendeskripsikan kemampuan komunikasi matematis siswa berkemampuan awal matematika rendah, sedang, dan tinggi baik pada aspek kemampuan gramatikal, sosiolinguistik, strategis, dan memahami wacana kelas VII SMP Negeri 1 Mojolaban tahun pelajaran 2014/2014.

\section{METODE PENELITIAN}

Penelitian ini merupakan penelitian kualitatif. Subjek dalam penelitian ini ditentukan melalui teknik purposive sampling sehingga diperoleh tujuh siswa kelas VIIE SMP Negeri 1 Mojolaban Tahun Pelajaran 2014/2015, yang terdiri dari tiga siswa berkemampuan awal matematika rendah, dua siswa berkemampuan awal matematika sedang, dan dua siswa berkemampuan awal matematika tinggi. Kategori kemampuan awal matematika tersebut dilihat berdasarkan nilai ulangan harian pada materi bilangan. Data dalam penelitian ini adalah kemampuan komunikasi matematis siswa pada aspek kemampuan gramatikal, sosiolinguistik, strategis, dan memahami wacana. Peneliti sebagai instrumen utama mengumpulkan sendiri data penelitian tersebut, sedangkan lembar tugas yang berisi soal tes dan pedoman wawancara dijadikan sebagai instrumen bantu. Teknik analisis data yang digunakan adalah reduksi data, penyajian data, dan 
penarikan kesimpulan.Validitas data dilakukan dengan triangulasi waktu yang membandingkan antara data wawancara berbasis tugas I dengan data wawancara berbasis tugas II. Data valid tentang kemampuan komunikasi matematis aspek gramatikal, sosiolinguistik, strategis, dan memahami wacana yang sama pada masing-masing kategori kemampuan awal siswa dijadikan sebagai temuan utama, sedangkan data valid yang berbeda dijadikan sebagai temuan lain penelitian.

\section{HASIL PENELITIAN}

Berdasarkan hasil analisis data sebelumnya, peneliti menemukan bahwa siswa berkemampuan awal matematika rendah, sedang, dan tinggi memiliki kemampuan komunikasi matematis pada aspek gramatikal, sosiolinguistik, strategis, dan memahami wacana yang belum memenuhi semua indikator dalam menyelesaikan soal. Peneliti menyajikan ringkasan kemampuan komunikasi matematis siswa berkemampuan awal matematika rendah, sedang, dan tinggi kelas VII SMP Negeri 1 Mojolaban pada aspek gramatikal, sosiolinguistik, strategis, dan memahami wacana dalam menyelesaikan soal seperti pada Tabel 1 . berikut ini.

Tabel 1. Kemampuan Komunikasi Matematis Subjek Penelitian

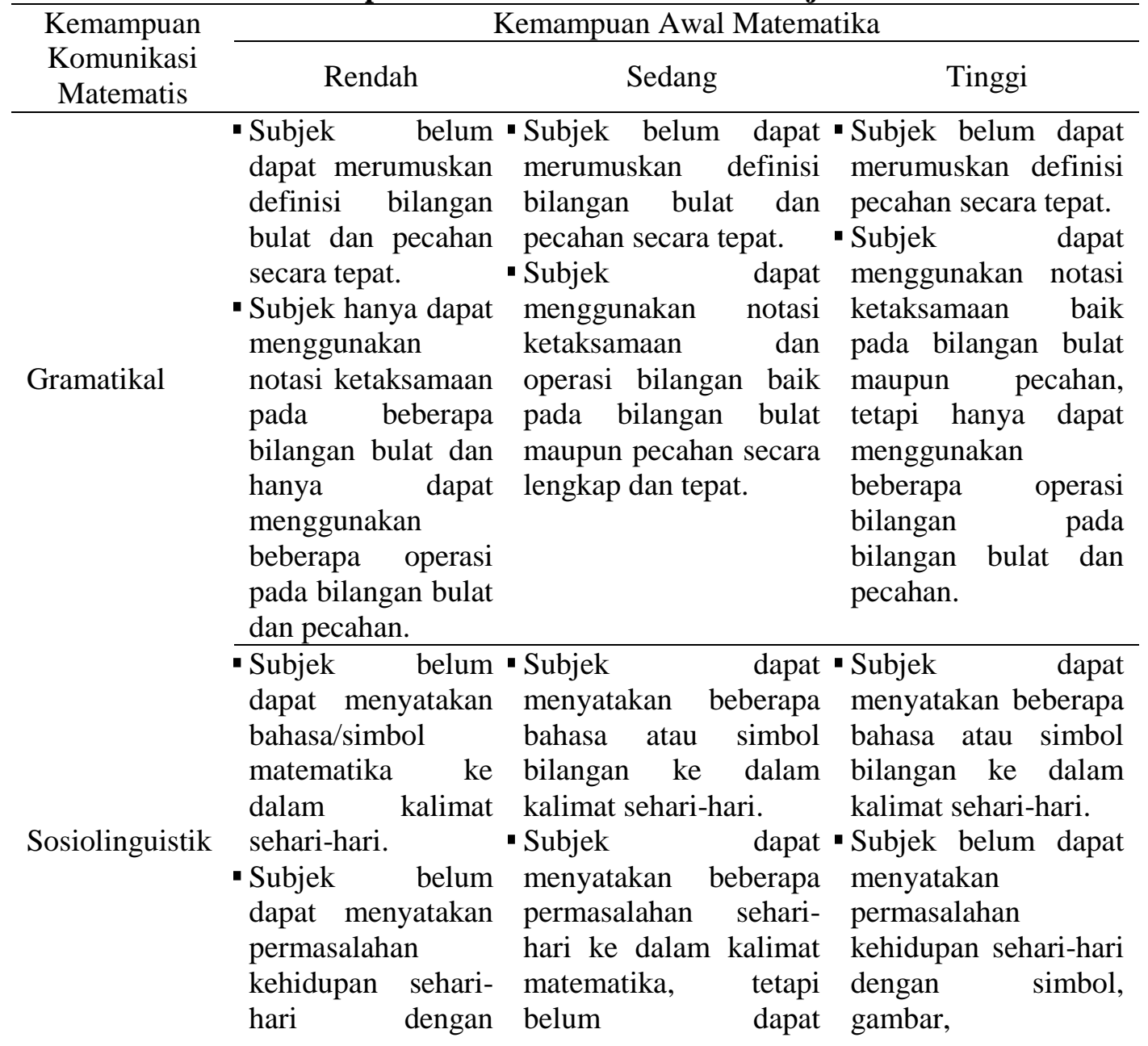




\begin{tabular}{|c|c|c|c|}
\hline \multirow{2}{*}{$\begin{array}{c}\text { Kemampuan } \\
\text { Komunikasi } \\
\text { Matematis }\end{array}$} & \multicolumn{3}{|c|}{ Kemampuan Awal Matematika } \\
\hline & Rendah & Sedang & Tinggi \\
\hline & $\begin{array}{l}\text { simbol, gambar, } \\
\text { bahasa/kalimat } \\
\text { matematika. } \\
\text { - Subjek belum } \\
\text { menarik } \\
\text { kesimpulan } \\
\text { terhadap persoalan } \\
\text { pecahan yang } \\
\text { diberikan. } \\
\text { - Subjek dapat } \\
\text { membaca notasi } \\
\text { ketaksamaan pada } \\
\text { bilangan bulat dan } \\
\text { pecahan. }\end{array}$ & $\begin{array}{l}\text { menyatakan } \\
\text { permasalahan } \\
\text { kontekstual tentang } \\
\text { selisih dan pecahan ke } \\
\text { dalam gambar } \\
\text { matematis. } \\
\text { - Subjek belum menarik } \\
\text { kesimpulan terhadap } \\
\text { persoalan bilangan } \\
\text { bulat dan pecahan yang } \\
\text { diberikan. } \\
\text { - Subjek dapat membaca } \\
\text { notasi ketaksamaan } \\
\text { pada bilangan bulat dan } \\
\text { pecahan. }\end{array}$ & $\begin{array}{l}\text { bahasa/kalimat } \\
\text { matematika. } \\
\text { - Subjek dapat } \\
\text { membaca notasi } \\
\text { ketaksamaan pada } \\
\text { bilangan bulat dan } \\
\text { pecahan. }\end{array}$ \\
\hline Strategis & $\begin{array}{l}\text { - Subjek menuliskan } \\
\text { informasi } \\
\text { mengenai apa yang } \\
\text { diketahui dari } \\
\text { persoalan bilangan } \\
\text { bulat dengan cara } \\
\text { menyalin soal } \\
\text { meskipun ada } \\
\text { beberapa bagian } \\
\text { yang tidak tepat, } \\
\text { tetapi tidak } \\
\text { menuliskan } \\
\text { informasi apa pun } \\
\text { dari persoalan } \\
\text { pecahan. } \\
\text { - Subjek } \\
\text { mendeskripsikan } \\
\text { strategi penentuan } \\
\text { selisih meskipun } \\
\text { tidak tepat, tetapi } \\
\text { tidak dapat } \\
\text { menjelaskan } \\
\text { strategi pada } \\
\text { penyelesaian soal } \\
\text { pecahan. }\end{array}$ & $\begin{array}{l}\text { - Subjek menuliskan } \\
\text { informasi mengenai apa } \\
\text { yang diketahui dari } \\
\text { persoalan bilangan } \\
\text { bulat dengan cara } \\
\text { merincinya meskipun } \\
\text { ada beberapa bagian } \\
\text { yang tidak lengkap, } \\
\text { tetapi tidak menuliskan } \\
\text { informasi apa pun dari } \\
\text { persoalan pecahan. } \\
\text { - Subjek pen } \\
\text { mendeskripsikan } \\
\text { strategi penentuan } \\
\text { selisih meskipun tidak } \\
\text { tepat dan dapat } \\
\text { mendeskripsikan } \\
\text { strategi penyelesaian } \\
\text { soal pecahan meskipun } \\
\text { tidak sampai pada hasil } \\
\text { akhir yang tepat. } \\
\text { - Subjek dapat } \\
\text { melakukan evaluasi } \\
\text { pada permasalahan } \\
\text { bilangan bulat. }\end{array}$ & $\begin{array}{lr}\text { - Subjek } & \text { tidak } \\
\text { menuliskan informasi } \\
\text { apa yang diketahui } \\
\text { dan apa yang } \\
\text { ditanyakan dari } \\
\text { persoalan pecahan. } \\
\text { - Subjek } \\
\text { mendeskripsikan } \\
\text { strategi penentuan } \\
\text { selisih meskipun } \\
\text { tidak tepat, tetapi } \\
\text { tidak dapat } \\
\text { menjelaskan strategi } \\
\text { pada penyelesaian } \\
\text { soal pecahan. } \\
\text { - Subjek dapat } \\
\text { melakukan evaluasi } \\
\text { pada persoalan } \\
\text { bilangan bulat. }\end{array}$ \\
\hline $\begin{array}{l}\text { Memahami } \\
\text { Wacana }\end{array}$ & $\begin{array}{l}\text { - Subjek tidak } \\
\text { memberikan } \\
\text { respon positif } \\
\text { terhadap } \\
\text { permasalahan yang } \\
\text { diberikan. } \\
\text { - Subjek } \\
\text { memberikan } \\
\text { pendapat pada soal } \\
\text { pecahan, tetapi } \\
\text { tidak diikuti }\end{array}$ & $\begin{array}{l}\text { - Subjek memberikan } \\
\text { respon positif terhadap } \\
\text { permasalahan yang } \\
\text { diberikan. } \\
\text { - Subjek memberikan } \\
\text { pendapat pada soal } \\
\text { bilangan bulat dengan } \\
\text { diikuti argumen yang } \\
\text { logis. }\end{array}$ & $\begin{array}{l}\text { - Subjek tidak } \\
\text { memberikan respon } \\
\text { positif terhadap } \\
\text { permasalahan yang } \\
\text { diberikan. } \\
\text { - Subjek memberikan } \\
\text { pendapat pada soal } \\
\text { bilangan bulat dengan } \\
\text { diikuti argumen logis, } \\
\text { sedangkan pada } \\
\text { pecahan tidak diikuti }\end{array}$ \\
\hline
\end{tabular}




\begin{tabular}{cll}
\hline $\begin{array}{c}\text { Kemampuan } \\
\text { Komunikasi } \\
\text { Matematis }\end{array}$ & \multicolumn{2}{c}{ Kemampuan Awal Matematika } \\
\cline { 2 - 3 } & Rengan argumen & \multicolumn{1}{c}{ Tinggi } \\
\hline yang logis. & argumen logis. \\
& & Subjek dapat \\
& membuat soal yang \\
& melibatkan operasi \\
& & penjumlahan, \\
& pengurangan, dan \\
& perkalian, secara \\
& pembagian \\
& terpisah. \\
\hline
\end{tabular}

Selanjutnya disajikan hasil temuan lain penelitian dengan karakteristik kemampuan komunikasi matematis pada aspek kemampuan gramatikal, sosiolinguistik, strategis, dan memahami wacana yang berbeda untuk masing-masing siswa dengan kategori kemampuan awal matematika redah, sedang, dan tinggi seperti berikut ini.

Tabel 2. Temuan Lain Penelitian Pada Aspek Gramatikal

\begin{tabular}{|c|c|}
\hline $\begin{array}{c}\text { Kemampuan } \\
\text { Awal } \\
\text { Matematika }\end{array}$ & Karakteristik yang Berbeda \\
\hline Rendah & $\begin{array}{l}\text { SRB dan SRC tidak dapat menggunakan notasi ketaksamaan } \\
\text { pada dua bilangan bulat negatif. } \\
\text { SRA dan SRB dapat menggunakan notasi ketaksamaan pada } \\
\text { pecahan, sedangkan SRC tidak dapat menggunakan notasi } \\
\text { ketaksamaan pada pecahan. } \\
\text { STA dapat merumuskan definisi bilangan bulat dengan tepat. } \\
\text { STA tidak dapat menggunakan operasi pembagian pada } \\
\text { bilangan bulat, sedangkan STB dapat menggunakan operasi } \\
\text { pembagian pada bilangan bulat. } \\
\text { STB dapat menggunakan operasi penjumlahan, pengurangan, } \\
\text { perkalian, dan pembagian pada pecahan. }\end{array}$ \\
\hline \multicolumn{2}{|c|}{ Tabel 3. Temuan Lain Penelitian Pada Aspek Sosiolinguistik } \\
\hline $\begin{array}{c}\text { Kemampuan } \\
\text { Awal Matematika }\end{array}$ & Karakteristik yang Berbeda \\
\hline Rendah & $\begin{array}{l}\text { SRA belum dapat menyatakan perbandingan simbol bilangan } \\
\text { bulat untuk menentukan suhu mana yang lebih dingin secara } \\
\text { tepat, sedangkan SRB dan SRC dapat menyatakan perbandingan } \\
\text { simbol bilangan bulat, kecuali jika keduanya menggunakan } \\
\text { bilangan bulat negatif. } \\
\text { SRA terbalik dalam pembacaan notasi ketaksamaan jika berdiri } \\
\text { secara sendiri-sendiri. }\end{array}$ \\
\hline Sedang & $\begin{array}{l}\text { SSA dapat menggunakan perbandingan pecahan dengan tepat, } \\
\text { sedangkan SSB tidak dapat menggunakan perbandingan pecahan } \\
\text { untuk menyelesaikan permasalahan sehari-hari. } \\
\text { STA menyatakan permasalahan sehari-hari mengenai kenaikan } \\
\text { dan penurunan suhu dengan menggunakan gambar garis } \\
\text { bilangan meskipun tidak tepat. } \\
\text { STB tidak menarik kesimpulan pada soal pecahan. }\end{array}$ \\
\hline
\end{tabular}


Tabel 4. Temuan Lain Penelitian Pada Aspek Strategis

\begin{tabular}{|c|c|}
\hline $\begin{array}{c}\text { Kemampuan } \\
\text { Awal Matematika }\end{array}$ & Karakteristik yang Berbeda \\
\hline Rendah & $\begin{array}{l}\text { SRA tidak melakukan evaluasi pada penyelesaian soal } \\
\text { bilangan bulat, sedangkan SRB dan SRC melakukan } \\
\text { evaluasi. } \\
\text { SRA melakukan evaluasi pada penyelesaian soal pecahan } \\
\text { meskipun tidak tepat, sedangkan SRB dan SRC tidak } \\
\text { melakukan evaluasi. }\end{array}$ \\
\hline Sedang & $\begin{array}{l}\text { SSA dapat melakukan evaluasi terhadap proses yang telah } \\
\text { dilakukan pada penyelesaian soal pecahan dengan tepat, } \\
\text { sedangkan SSB tidak melakukan evaluasi. }\end{array}$ \\
\hline Tinggi & $\begin{array}{l}\text { STB menuliskan apa yang diketahui pada persoalan bilangan } \\
\text { bulat meskipun ada beberapa bagian yang tidak tepat. } \\
\text { STA melakukan evaluasi terhadap proses yang telah } \\
\text { dilakukan pada penyelesaian soal pecahan meskipun tidak } \\
\text { tepat, sedangkan STB tidak melakukan evaluasi. }\end{array}$ \\
\hline \multicolumn{2}{|c|}{ Tabel 5. Temuan Lain Penelitian pada Aspek Memahami Wacana } \\
\hline $\begin{array}{c}\text { Kemampuan } \\
\text { Awal Matematika }\end{array}$ & Karakteristik yang Berbeda \\
\hline Rendah & $\begin{array}{l}\text { SRA memberikan pendapat pada persoalan bilangan bulat } \\
\text { tetapi tidak diikuti dengan argumen atau penjelasan yang } \\
\text { logis, sedangkan SRB dan SRC memberikan pendapat diikuti } \\
\text { dengan argumen logis. } \\
\text { SRA dan SRB dapat membuat soal yang melibatkan operasi } \\
\text { perkalian, pembagian, penjumlahan, dan pengurangan pada } \\
\text { bilangan bulat dan pecahan secara terpisah, sedangkan SRC } \\
\text { tidak dapat membuat soal yang melibatkan keempat operasi } \\
\text { baik secara terpisah maupun sekaligus. }\end{array}$ \\
\hline Sedang & $\begin{array}{l}\text { SSA memberikan pendapat pada persoalan pecahan dan } \\
\text { diikuti dengan argumen logis, sedangkan SSB tidak diikuti } \\
\text { dengan argumen logis. } \\
\text { SSA membuat soal yang melibatkan operasi perkalian, } \\
\text { pembagian, penjumlahan, dan pengurangan pada bilangan } \\
\text { bulat dan pecahan secara terpisah, sedangkan SSB membuat } \\
\text { soal pada bilangan bulat dan pecahan yang melibatkan } \\
\text { keempat operasi sekaligus. }\end{array}$ \\
\hline
\end{tabular}

Berdasarkan kemampuan komunikasi matematis pada Tabel.1, 2, 3, 4, dan 5 peneliti dapat menguraikan tentang persamaan dan perbedaan karakteristik kemampuan komunikasi matematis siswa dengan kategori kemampuan awal matematika rendah, tinggi, dan sedang pada aspek kemampuan gramatikal, sosiolinguistik, strategis, dan memahami wacana seperti berikut ini.

1.

\section{Aspek Gramatikal}

Siswa dengan kategori kemampuan awal matematika sedang dan rendah sama-sama belum dapat merumuskan definisi bilangan bulat secara tepat. Mereka hanya sebatas pada pengidentifikasian contoh dan bukan contoh. Hanya saja, siswa berkemampuan rendah mengidentifikasi bilangan-bilangan positif saja yang termasuk ke dalam contoh bilangan bulat, sedangkan siswa berkemampuan sedang dapat 
mengidentifikasi semua contoh bilangan bulat secara lengkap baik bilangan bulat positif, nol, dan negatif secara tepat. Meskipun demikian, peneliti menemukan ada satu siswa dari kategori kemampuan tinggi yang dapat merumuskan definisi bilangan bulat dengan tepat dan sistematis. Selanjutnya, semua kategori kemampuan siswa dalam penelitian ini belum ada yang dapat merumuskan definisi pecahan. Mereka hanya dapat mengidentifikasi beberapa contoh pecahan secara tepat dan mengalami kesalahan pada beberapa pengidentifikasian contoh pecahan. Hal ini disebabkan karena definisi pecahan yang mereka miliki kurang spesifik.

Siswa berkemampuan awal matematika tinggi dan sedang dapat menggunakan notasi ketaksamaan pada bilangan bulat dan pecahan secara tepat, sedangkan siswa berkemampuan awal matematika rendah hanya dapat menggunakan notasi ketaksamaan pada beberapa bilangan bulat saja. Subjek berkemampuan rendah mengalami kesalahan penggunaan notasi ketaksamaan jika diaplikasikan untuk membandingkan dua bilangan bulat negatif. Selanjutnya, siswa berkemampuan sedang dapat menggunakan operasi bilangan penjumlahan, pengurangan, perkalian, dan pembagian secara lengkap baik pada bilangan bulat maupun pecahan, sedangkan siswa berkemampuan tinggi dan rendah hanya dapat menggunakan beberapa operasi bilangan saja. Hal ini menunjukkan bahwa siswa berkemampuan sedang lebih unggul pada aspek gramatikal, khususnya dalam penggunaan operasi bilangan pada bilangan bulat dan pecahan.

2.

Aspek Sosiolinguistik

Siswa berkemampuan awal matematika rendah tidak memiliki kemampuan sosiolinguitik yang baik. Mereka belum dapat menyatakan bahasa/simbol matematika ke dalam kalimat sehari-hari, tidak dapat menyatakan permasalahan dalam kehidupan sehari-hari dengan simbol, gambar, bahasa/kalimat matematika, belum menarik kesimpulan terhadap persoalan pecahan. Meskipun demikian, mereka dapat membaca notasi ketaksamaan pada bilangan bulat dan pecahan. Selanjutnya, siswa berkemampuan sedang memiliki karakterististik kemampuan sosiolinguistik yang lebih banyak dibandingkan siswa berkemampuan rendah. Mereka dapat membaca notasi ketaksamaan pada bilangan bulat dan pecahan, dapat menyatakan beberapa bahasa atau simbol bilangan ke dalam kalimat sehari-hari, dapat menyatakan beberapa permasalahan sehari-hari ke dalam kalimat matematika, tetapi belum dapat menyatakan persoalan kontekstual tentang selisih dan pecahan ke dalam gambar matematis dan belum menarik kesimpulan terhadap permasalahan bilangan bulat dan pecahan yang diberikan. Sedangkan siswa berkemampuan tinggi memiliki kemampuan sosiolinguistik yang tidak berbeda jauh dengan siswa berkemampuan 
sedang. Mereka juga dapat membaca notasi ketaksamaan pada bilangan bulat dan pecahan, dapat menyatakan beberapa bahasa atau simbol bilangan ke dalam kalimat sehari-hari, tetapi belum dapat menyatakan persoalan kontekstual dengan simbol, gambar, bahasa/kalimat matematika.

Ketiga kategori siswa tidak terlalu mengalami perbedaan pada kemampuan sosiolinguistik, khususnya pada karakteristik dalam menyatakan persoalan kontekstual dengan menggunakan gambar matematis. Siswa belum dapat menyatakan konsep selisih ke dalam gambar garis bilangan secara tepat karena mereka mengalami kesalahan pemahaman konsep selisih (miskonsepsi). Selain itu, mereka juga tidak terbiasa menyatakan permasalahan kontekstual ke dalam gambar matematis terlebih dahulu ketika menyelesaikan soal.

3. Aspek Strategis

Siswa berkemampuan rendah dan sedang sama-sama menuliskan informasi mengenai apa yang diketahui dari soal bilangan bulat terlebih dahulu, hanya saja siswa berkemampuan rendah menuliskan informasi tersebut seperti menyalin ulang informasi soal dengan beberapa bagian yang tidak tepat, sedangkan siswa berkemampuan sedang menuliskan dengan cara merinci dan lebih spesifik meskipun ada beberapa bagian yang tidak cepat juga. Meskipun demikian, ketiga kategori siswa tidak menuliskan informasi tentang apa yang diketahui dan ditanyakan dari soal pecahan.

Ketiga kategori siswa dapat mendeskripsikan strategi untuk menentukan selisih meskipun tidak tepat. Ketidaktepatan ini disebabkan karena mereka menganggap konsep selisih sebatas pada prosedur pengurangan saja dan bukan jarak antara dua bilangan. Selain itu, siswa berkemampuan rendah dan tinggi sama-sama tidak dapat mendeskripsikan strategi penyelesaian soal pada pecahan, sedangkan siswa berkemampuan sedang dapat mendeskripsikan strateginya meskipun tidak dampai pada hasil akhir yang tepat. Selanjutnya, siswa berkemampuan sedang dan tinggi dapat melakukan evaluasi pada soal bilangan bulat secara tepat, sedangkan siswa berkemampuan rendah ada yang dapat melakukan evaluasi secara tepat dan ada siswa yang tidak dapat melakukan evaluasi sama sekali.

4. Aspek Memahami Wacana

Siswa berkemampuan sedang dapat memberikan respon positif terhadap permasalahan yang diberikan. Mereka dapat menjelaskan ide-ide yang diberikan secara lisan meskipun terkadang terdapat lompatan-lompatan dalam penjelasannya. Mereka dapat berkomunikasi secara efektif, sehingga penjelasannya mudah dimengerti. Sebaliknya, siswa berkemampuan tinggi dan rendah sama-sama tidak 
dapat memberikan respon positif terhadap permasalahan yang diberikan. Mereka kesulitan menyampaikan ide-idenya secara lisan dan banyak diam ketika diminta menjelaskan. Meskipun demikian, siswa berkemampuan tinggi terkadang memberikan gerakan-gerakan tangan agar maksud atau gagasannya lebih mudah ditangkap peneliti, sedangkan siswa berkemampuan rendah lebih banyak berkomunikasi secara tidak efektif, bahkan terkadang menyampaikan penjelasan yang tidak mencerminkan masalah.

Selanjutnya, siswa berkemampuan tinggi dan sedang memberikan perdapat pada soal pecahan tetapi tidak diikuti dengan argumen logis, sedangkan pada kategori kemampuan sedang ada siswa yang dapat memberikan pendapat dengan diikuti argumen logis. Selain itu, siswa berkemampuan sedang dan tinggi memberikan pendapat pada soal bilangan bulat dengan diikuti argumen logis, sedangkan pada kategori rendah ada siswa yang memberikan pendapat tetapi tidak diikuti dengan argumen logis. Selain itu, peneliti menemukan bahwa ada siswa berkemampuan tinggi yang dapat membuat satu soal dengan langsung melibatkan keempat operasi bilangan sekaligus dan menemukan ada siswa dari kategori rendah yang tidak dapat membuat soal bilangan bulat dan pecahan sama sekali.

Berdasarkan hasil penelitian ini, peneliti menemukan bahwa pada masingmasing kategori kemampuan awal matematika yang sama maupun berbeda terkadang muncul karakteristik pada aspek gramatikal, sosiolinguistik, strategis, dan memahami wacana yang berbeda. Misalnya, siswa sama-sama menuliskan informasi dari soal, tetapi penulisan siswa yang satu dilakukan dengan cara menyalin soal, sedangkan siswa yang lain menulis dengan cara merinci secara lebih spesifik. Hal ini menunjukkan bahwa kemungkinan kemampuan komunikasi matematis pada aspek gramatikal, sosiolinguistik, strategis, dan memahami wacana bersifat hierarkis, sehingga ada perbedaan karakteristik masing-masing aspeknya. Kehierarkisan masingmasing aspek komunikasi matematis ini bisa saja terjadi sebagaimana penelitian Zavy (2012). Selain itu, hasil penelitian ini menunjukkan bahwa kemampuan komunikasi matematis siswa tidak dipengaruhi sepenuhnya oleh kemampuan awal matematika siswa tetapi juga dipengaruhi tahapan perkembangan kognitif siswa dan hasil pembelajaran. Lemahnya kemampuan komunikasi matematis pada penelitian ini kemungkinan dipengaruhi oleh beberapa faktor, antara lain: (1) tahap perkembangan kognitif siswa, dimana kemungkinan ada siswa yang pemikirannya masih didominasi oleh pemikiran operasional konkret dibandingkan pemikiran operasional formal; (2) munculnya kesalahan pemahaman terhadap konsep matematika (miskonsepsi); (3) adanya penggunaan kata kunci (keyword) dalam menyelesaikan soal yang dapat 
menyesatkan siswa (misleading); (4) lemahnya pemahaman tentang konsep bilangan dan hubungannya dengan operasi bilangan; (5) pembelajaran di SMP yang kurang memberikan latihan soal agar dapat mengembangkan kemampuan komunikasi matematis siswa, khususnya pada aspek sosiolinguistik, strategis, dan memahami wacana. Menurut Olivares (1996), penyebab ini dapat digolongkan sebagai faktor yang berkaitan dengan sumber kognitif (cognitif resources) dan faktor heuristik (heuristics). Olivares (1996:225) menyatakan bahwa sumber kognitif (cognitif resources) meliputi pengetahuan dasar matematika siswa tentang fakta matematika, konsep, dan algoritma, dimana sumber kognitif (cognitif resources) tersebut dipengaruhi oleh usia dan dasar pendidikan yang telah mereka terima di sekolah, sedangkan faktor heuristik (heuristic) meliputi pengidentifikasian strategi umum dalam penyelesaian masalah.

\section{SIMPULAN DAN SARAN}

Berdasarkan hasil penelitian dan pembahasan tentang kemampuan komunikasi matematis siswa berkemampuan rendah, sedang, dan tinggi kelas VII SMP Negeri 1 Mojolaban dapat disimpulkan sebagai berikut. 1) Kemampuan komunikasi matematis siswa berkemampuan awal matematika rendah, yaitu: (a) pada kemampuan gramatikal, siswa belum dapat merumuskan definisi bilangan bulat dan pecahan, dapat menggunakan notasi ketaksamaan pada beberapa bilangan bulat dan dapat menggunakan beberapa operasi pada bilangan bulat dan pecahan; (b) pada kemampuan sosiolinguistik, siswa belum dapat menyatakan bahasa/simbol matematika ke dalam kalimat sehari-hari, belum dapat menyatakan permasalahan kehidupan sehari-hari dengan simbol, gambar bahasa/kalimat matematika, belum menarik kesimpulan pada soal pecahan, tetapi dapat membaca notasi ketaksamaan pada bilangan bulat dan pecahan; (c) pada kemampuan strategis, siswa menuliskan informasi tentang apa yang diketahui dari soal bilangan bulat dengan cara menyalin soal meskipun ada beberapa bagian yang tidak tepat dan tidak menuliskan informasi tentang apa yang diketahui dan ditanyakan pada soal pecahan, dapat mendeskripsikan strategi penentuan selisih meskipun tidak tepat, tetapi tidak dapat menjelaskan strategi penyelesaian soal pecahan; (d) pada kemampuan memahami wacana, siswa tidak memberikan respon positif terhadap permasalahan yang diberikan, memberikan pendapat pada soal pecahan tetapi tidak diikuti dengan argumen yang logis; 2) Kemampuan komunikasi matematis siswa berkemampuan awal matematika sedang, yaitu: (a) pada kemampuan gramatikal, siswa belum dapat merumuskan definisi bilangan bulat dan pecahan secara tepat; dapat menggunakan notasi ketaksamaan pada bilangan bulat dan pecahan secara tepat; dan dapat menggunakan operasi penjumlahan, 
pengurangan, perkalian, dan pembagian baik pada bilangan bulat maupun pada pecahan; (b) pada kemampuan sosiolinguistik, siswa dapat menyatakan beberapa bahasa/simbol bilangan ke dalam kalimat sehari-hari; dapat menyatakan beberapa permasalahan kehidupan sehari-hari dengan kalimat matematika tetapi belum dapat menyatakan permasalahan tentang selisih dan pecahan ke dalam gambar matematis; belum menarik kesimpulan pada soal bilangan bulat dan pecahan; dan dapat membaca notasi ketaksamaan pada bilangan bulat dan pecahan; (c) pada kemampuan strategis, siswa menuliskan informasi tentang apa yang diketahui dari soal bilangan bulat dengan cara merincinya tetapi ada beberapa bagian yang tidak lengkap dan tidak menuliskan informasi tentang apa yang diketahui dan ditanyakan pada soal pecahan; dapat mendeskripsikan strategi penentuan selisih meskipun tidak tepat dan dapat mendeskripsikan strategi penyelesaian soal pecahan meskipun tidak sampai pada hasil akhir yang tepat; (d) pada kemampuan memahami wacana, siswa memberikan respon positif terhadap permasalahan yang diberikan; memberikan pendapat pada soal bilangan bulat dengan diikuti argumen yang logis; 3) Kemampuan komunikasi matematis siswa berkemampuan awal matematika tinggi, yaitu: (a) pada kemampuan gramatikal, siswa belum dapat merumuskan definisi pecahan secara tepat; siswa dapat menggunakan notasi ketaksamaan baik pada bilangan bulat maupun pecahan; dan dapat menggunakan beberapa operasi pada bilangan bulat dan pecahan; (b) pada kemampuan sosiolinguistik, siswa dapat menyatakan beberapa bahasa/simbol bilangan ke dalam kalimat sehari-hari; tidak dapat menyatakan permasalahan kehidupan sehari-hari dengan simbol, gambar bahasa/kalimat matematika, dan dapat membaca notasi ketaksamaan pada bilangan bulat dan pecahan; (c) pada kemampuan strategis, siswa tidak menuliskan informasi tentang apa yang diketahui dan ditanyakan pada soal pecahan; dapat mendeskripsikan strategi penentuan selisih meskipun tidak tepat dan tidak dapat mendeskripsikan strategi penyelesaian soal pecahan; dan siswa dapat melakukan evaluasi pada soal bilangan bulat; (d) pada kemampuan memahami wacana, siswa tidak memberikan respon positif terhadap permasalahan yang diberikan; memberikan pendapat pada soal bilangan bulat dengan diikuti argumen yang logis, sedangkan pada soal pecahan tidak diikuti dengan argumen logis; dapat membuat soal yang melibatkan operasi penjumlahan, pengurangan, perkalian, dan pembagian secara terpisah.

Adapun saran yang bisa disampaikan dari penelitian ini adalah sebagai berikut. (1) Bagi peneliti lain yang tertarik dengan penelitian ini dapat melakukan penelitian lebih lanjut tentang kemampuan komunikasi matematis pada aspek gramatikal, sosiolinguistik, strategis, dan memahami wacana dengan melakukan penjenjangan terlebih dahulu terhadap karakteristik masing-masing aspek komunikasi matematis tersebut; (2) Bagi 
guru sebaiknya memberikan pembelajaran yang memungkinkan siswa dapat mengembangkan kemampuan komunikasi matematis pada aspek gramatikal, sosiolinguistik, strategis, dan memahami wacana seperti berikut ini. (1) Memperkenalkan definisi secara spesifik terhadap suatu konsep maupun istilah matematika; (2) Memberikan lebih banyak soal-soal kontekstual dengan alternatif solusi yang beragam agar dapat diselesaikan siswa; (3) Membimbing siswa agar terbiasa membuat gambar/sketsa terlebih dahulu ketika menyelesaikan soal agar mudah memahami masalah; (3) Membuat kelompok kecil untuk melatih kemampuan siswa dalam menjelaskan argumennya kepada siswa lain.

\section{DAFTAR PUSTAKA}

Ali Mahmudi.2009.Komunikasi dalam Pembelajaran Matematika.Jurnal MIPA UNHALU. Vol.8. No.1. 1-9.

Kongthip, Y., Inprasitha, M., Pattanajak, A., \& Inprasitha, N.2012. Mathematical Communication by 5th Grade Student's Gestures in Lesson Study and Open Approach Context. Thailand:SciRes.

Kosko, K.W. dan Wilkins, J.L.M.2011.Mathematical Communication and Its Relation to The Frequency of Manipulative Use.International Electronic Journal of Mathematics Education. Vol.5. No.2. 79-90.

National Council of Teachers of Mathematics (NCTM).2000. Principles and Standards for School Mathematics. Reston VA: NCTM.

Olivares, R.A. 1996. Communication in Mathematics for Students with Limited English Proficiency,hlm.221-230. dalam Portia C Elliot dan Margaret J (edt).Communication in Mathematics K-12 and Beyond. Reston VA:NCTM.

Ontario Ministry of Education.2010.Capacity Building Series.Ontario:The Literacy and Numeracy Secretariat.

Zavy Sulthani.2012.Kemampuan Komunikasi Matematis Siswa Kelas Unggulan dan Siswa Kelas Reguler Kelas X SMA Panjura Malang Pada Materi Logika Matematika. Malang: Universitas Negeri Malang. 